\title{
The Effect of on-Street Parking on Vehicle Velocity and Level of Service at Cik Di Tiro Street Yogyakarta
}

\author{
Benni Mustofa, Retna Hidayah
}

\begin{abstract}
On-street Parking activities on the curb of streets can disrupt the traffic flow and cause traffic congestion. This study aimed to examine the effect of On-street Parking on vehicle velocity and Level of Service (LO). This research was conducted on Cik Di Tiro Street, around Panti Rapih Hospital, Yogyakarta. The analysis of road segmentation was guided by the Indonesian highway capacity manual (1997). The analysis results revealed that during weekdays, the vehicle velocity in the morning without any On-Street Parking was 29.45 kilometers per hour, while the level of service was at level $C$, meanwhile, in the afternoon, and in the evening, the vehicle velocity was 21,672 kilometers per hour with the parking accumulation as many as 1-2 light vehicles, 4-18 motorcycles, and the level of service was at level E. Meanwhile, in the weekend, the vehicle velocity in the morning without On-street Parking was 29.16 kilometers per hour, and the level of service was at level A. Meanwhile, in the afternoon and evening, the vehicle speed was 23.04 kilometers per hour, with the parking accumulation as many as 1-3 light vehicles, 1-14 motorycles, and the level of services were at Level $D$ and $C$ in the afternoon.
\end{abstract}

Keywords: On-street Parking, Capacity, Velocity, Level of Service.

\section{INTRODUCTION}

The population growth in Yogyakarta have been increasing, many visitors and students come from various regions for having recreation and studying in Yogyakarta. The increase in population and visitors also support people in Yogyakarta to improve the income. One of the people's ways to improve the income is by selling food on the curb of the road. Indonesian Labor Organization (2002) noted that homeworkers and street vendors are the largest subgroup on the fillers job and also contributors to employment opportunities in the trade sector, as much as $93 \%$ of total employment opportunities [1]. Street vendors generally do not have parking spaces, forcing consumers to park on the curb of the road, but it affects the On-street Parking activities and disrupts the traffic flow since the capacity of the road becomes narrow and make congestion [2] [3]. Parking is an important element and a common problem of urban transportation planning and research [4] [5] [6] [7]. The

Revised Manuscript Received on January 03, 2020.

* Correspondence Author

Benni Mustofa*, Vocational and Technology Education of Postgraduate Program, Yogyakarta State University, 55281 Yogyakarta, Indonesia. Email: bennimustofa.2018@student.uny.ac.id

Retna Hidayah, Faculty of Engineering, Yogyakarta State University, 55281 Yogyakarta, Indonesia. Email: retnadewa@yahoo.com

(c) The Authors. Published by Blue Eyes Intelligence Engineering and Sciences Publication (BEIESP). This is an open access article under the CC BY-NC-ND license (http://creativecommons.org/licenses/by-nc-nd/4.0/)

Published By:

Blue Eyes Intelligence Engineering \& Sciences Publication (C) Copyright: All rights reserved.

traffic disruption is caused by a lack of parking spaces, especially in the center of the city [8]. Meanwhile, the vehicles absolutely require parking space in each destination, besides the parameters that determine the trip [9].

When the curb of the street is used as a parking, it will reduce the capacity of the road in two ways. First, On-Street Parking narrows the width of the road and disrupts the traffic flow since the vehicles' movement is limited and automatically reduces their speed. Second, maneuvers that cannot park creates a complex situation which causes traffic jams on urban roads [10]. One of the examples of On-street Parking is on Cik Di Tiro Street, Yogyakarta.

Cik Di Tiro street (where Panti Rapih Hospital is located) is an urban road in Yogyakarta which has quite high activity. Murray [11] argues that a challenge for urban planners and decision-makers is to identify effective strategies for dealing with traffic disruptions and public transportation. Several studies which focused on road space with parking maneuvers had revealed that there was a reduction in road capacity [12] [13]. Also , Ye [14] has analyzed that traffic delay was caused by parking maneuvers based on the length of the nearest intersection, and the delay was getting longer. Cik Di Tiro street is located in front of Gajah Mada University roundabout, while Cik Di Tiro street is a cultivation area, where hospitals, schools, universities, offices, shops, and banks are available on the street. It causes high activities and crowds on Cik Di Tiro street.

This research conducted to examine how much the decrease in vehicle velocity and level of services due to the On-street Parking activity at Cik Di Tiro Street, Yogyakarta. In this study, the disruption factor is based on the real condition without any special treatment.

\section{MATERIALS AND METHODS}

\section{A. Research Location}

There are 3 streams of vehicles passing through the research location, which are terban road, Pancasila road and colombo road. researchers chose this location because it is one of the streets with street vendors and consumers of street vendors parking on the street. The illustration of the location of the research and the vehicle flow are as follows:

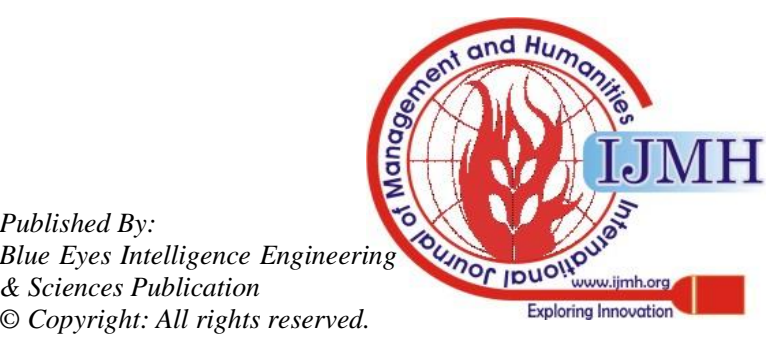




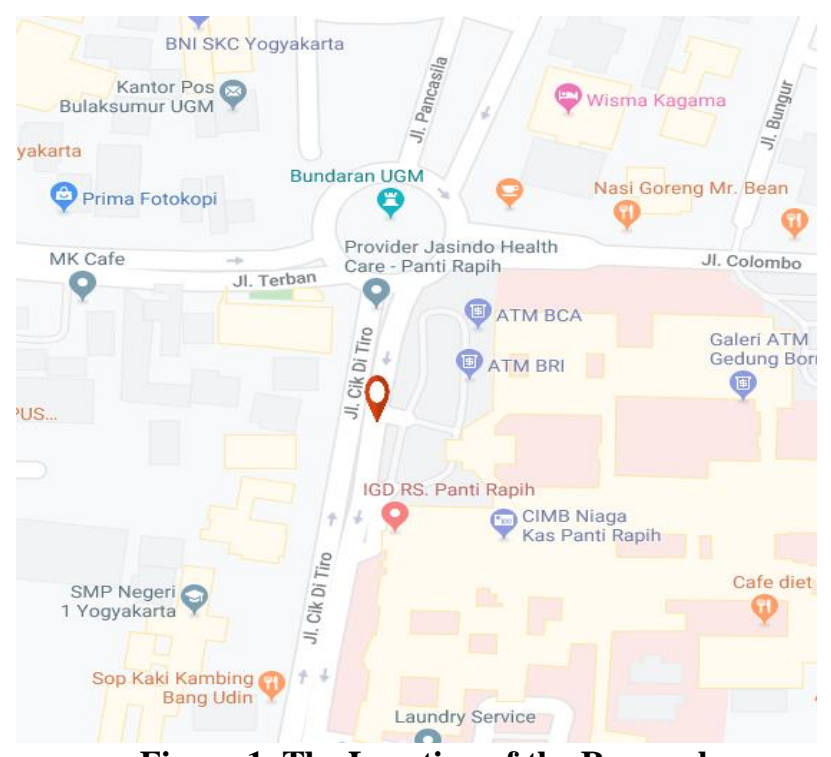

Figure 1. The Location of the Research

\section{B. Data Collection Schedules}

The data collection schedules were adjusted based on the office hours in Yogyakarta, where the vehicle flow approached the saturation point and capacity. Data were collected on weekdays and weekends, such as on Monday, Wednesday, and Friday in order to represent workdays/weekdays and Saturdays to represent holidays/weekends. The schedule to collect the data were as follows: Monday (Morning at $7 \mathrm{am}$ to $8 \mathrm{am}$; Afternoon at $12.15 \mathrm{am}$ to $13.15 \mathrm{pm}$, Evening at $15.30 \mathrm{pm}$ to $16.30 \mathrm{pm}$ ); Wednesday (morning at 7 am to $8 \mathrm{am}$, Afternoon at 12.15 am to $13.15 \mathrm{pm}$, Afternoon at $15.30 \mathrm{pm}$ to $16.30 \mathrm{pm}$ ); Friday (Morning at 7 am to $8 \mathrm{am}$, Afternoon at $10.30 \mathrm{am}$ to $11.30 \mathrm{am}$, afternoon at $15.30 \mathrm{pm}$ to $16.30 \mathrm{pm})$; and Saturday (Morning at 7 am to $8 \mathrm{am}$, Afternoon at $12.15 \mathrm{am}$ to $13.15 \mathrm{am}$, and Evening at $7 \mathrm{pm}$ to $8 \mathrm{pm}$ ).

\section{Roadway Geometric Data}

The length of the road segmentation was 152 meters, from the roundabout of Panti Rapih Hospital to Bank BPD Yogyakarta. Road segmentations were measured in order to calculate the velocity, Vehicle velocity is the division between distance and time.

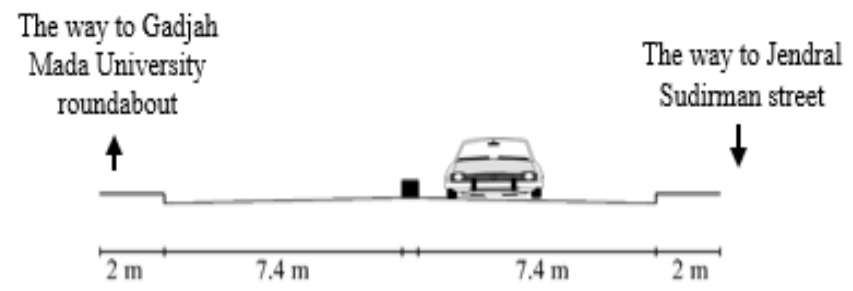

Figure 2. Roadway Geometric

Geometric data shows the calculations that will be used according to the analysis of two-lane and two-way urban areas of Indonesian road capacity manuals.

\section{City Size Classes}

The research was conducted in Yogyakarta city areas. Capacity will be calculated with the city size factor was determined by using a coefficient of FCCS $=0.90$.

Tabel 1. The Number of Populations in Yogyakarta

$$
\begin{gathered}
\text { The Number of } \\
\text { Populations }
\end{gathered}
$$

\begin{tabular}{lr}
\hline Kulon Progo & 430,220 \\
\hline Bantul & $1,018,402$ \\
\hline Gunung Kidul & 742,731 \\
\hline Sleman & $1,219,640$ \\
\hline Yogyakarta City & 431,939 \\
\hline Special Region of & $3,842,932$ \\
\hline Yogyakarta (Province) & Source: Indonesian Central Statistics Agency [15]
\end{tabular}

E. The Parameter of Road Performance

The volume of traffic flow (Q) was calculated by using the following formula :

$\mathrm{Q}=(\mathrm{empLV} x \mathrm{LV})+(\mathrm{empHV} x \mathrm{HV})+(\operatorname{empMC} \mathrm{x} \mathrm{Mc})[16]$

Explanations:

LV : Light Vehicle

HV : Heavy Vehicle

MC : Motorcycle

The volume of traffic flow is calculated and compared with the capacity to see the degree of saturation and service level of the road.

The road capacity (C) was calculated by using the following formula:

C = Co x FCw x FCsp x FCsf x FCcs [16]

Explanations

Co :Core capacity (deviation/hour)

FCw : effective track width adjustment factor

FCsp : splitting direction adjustment factor

FCsf : side friction adjustment factor

FCcs : city size adjustment factor

The capacity is the limit of road saturation. when the near capacity, a small increase in flow results in a large decrease in velocity [3]

The velocity (V) was calculated by using the following formula :

$\mathrm{V}=\mathrm{L} / \mathrm{TT}[16]$

Explanations:

$\mathrm{V}$ : The average velocity of Light Vehicle (kilometers/hour) $\mathrm{L} \quad$ : The length of the segmentation (kilometer)

TT : The average time of Light Vehicle accross the segmentation (hour)

The velocity is a distinguishing factor that affects on-street parking and without on-street parking in this study.

The degree of saturation (Ds) was calculated by using the following formula:

Ds $=\mathrm{Q} / \mathrm{C}[16]$

Explanations:

$\mathrm{Q}$ : The volume of traffic flow (deviation/hour)

$\mathrm{C}$ : Capacity (deviation/hour)

The degree of saturation determines the level of service. Scope limit the degree of saturation from 0,0-1,0. The Characteristics of Level of Service (LOS) are as follows.

\& Sciences Publication

(C) Copyright: All rights reserved.

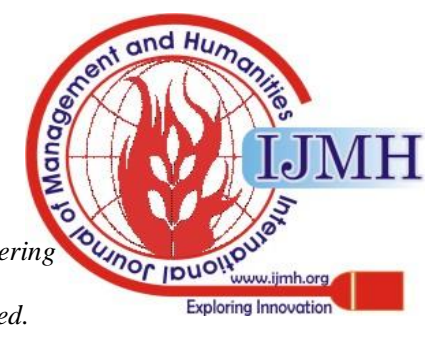


Table 2. The Characteristics of Level of Service (LOS)

\begin{tabular}{ccc}
\hline LOS & Characteristics & Scope Limit \\
\hline A & The traffic flow is free, high velocity, and & $0,0-0,20$ \\
no disruption. & \\
\hline B & $\begin{array}{c}\text { The traffic flow is stable, the velocity is } \\
\text { limited based on the traffic condition. }\end{array}$ & $0,21-0,44$ \\
\hline C & $\begin{array}{c}\text { The traffic flow is stable, velocity and } \\
\text { movement are controlled. }\end{array}$ & $0,45-0,74$ \\
\hline D & $\begin{array}{c}\text { The traffic flow is nearly unstable, the } \\
\text { velocity is controlled. }\end{array}$ & $0,75-0,84$ \\
\hline E & $\begin{array}{c}\text { The traffic flow is nearly / in unstable } \\
\text { condition, sometimes it stops. }\end{array}$ & $0,85-1,00$ \\
\hline F & $\begin{array}{c}\text { The traffic flow is terrible / traffic } \\
\text { congestion, low velocity, and any great } \\
\text { traffic disruptions. }\end{array}$ & $>1,00$ \\
\hline
\end{tabular}

Source [16]

\section{RESULTS AND DISCUSSION}

\section{A. The Velocity and Parking Volume}

The Vehicle flow velocity is one of the determinants that the vehicle is running smoothly or obstructed, and slowing the vehicle can cause congestion on the road. Vehicle velocity was measured in order to see how much the effects of On-street Parking activity in decrease vehicle velocity.

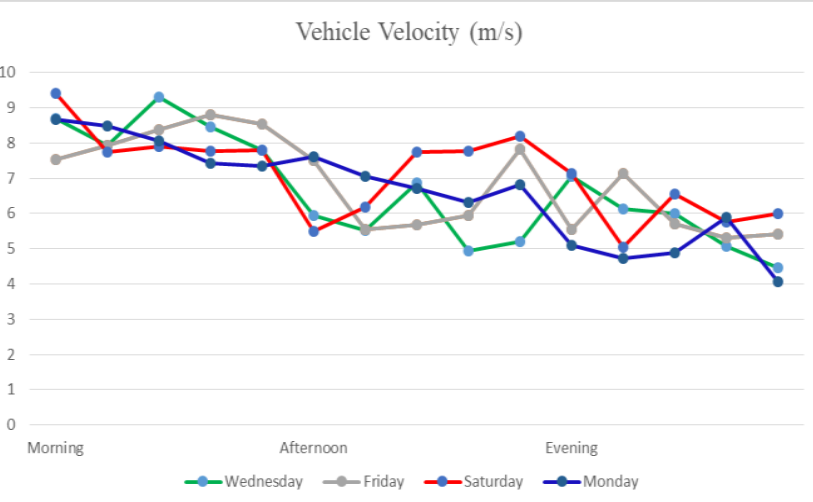

Figure 3. Data of Vehicle Velocity per 15 minutes $(\mathrm{m} / \mathrm{s})$

The vehicle velocity and the number of parking was calculated per 15 minutes to see the effect of parking on velocity. based on the data of vehicle velocity graph shows that the velocity tends to decrease from morning (without on-street parking) to afternoon (on-street parking) and evening (on-street parking), this is in accordance with the graph of the number of parking vehicles as below:

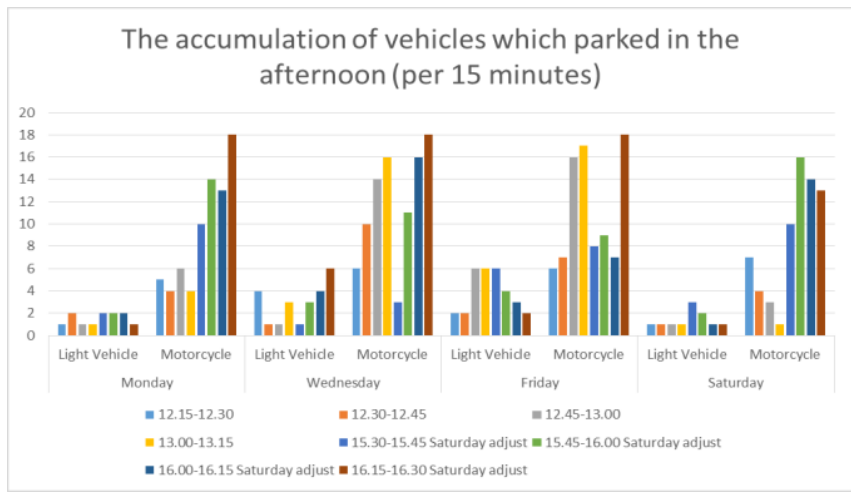

Figure 4. The Vehicle Parking Accummulation

From the both of graph, it was revealed that vehicle velocity had been decreased by the increasing parking accumulation, so it can be concluded:
1. Vehicle velocity average on weekdays (in the morning) was 29,45 kilometers/hour without any On-Street Parkings. Meanwhile, in the afternoon and evening, the velocity decreased to 21,672 kilometers / hour with accumulation of parking as many as 1-2 light vehicles and 4- 18 motorcycles. the data shows a decrease in velocity of 7,78 kilometers/hour due to on-street parking.

2. Vehicle velocity average on weekends (in the morning) was 29.16 kilometers / hour without any On-Street Parkings. Meanwhile, in the afternoon and evening, the velocity decreased to to $23,04 \mathrm{~km} \mathrm{/} \mathrm{hour} \mathrm{with}$ accumulation of parking as many as 1-3 light vehicles and 1-14 motorbikes. the data shows a decrease in velocity of 6,12 kilometers/hour due to on-street parking.

\section{B. Level of Service (LOS)}

Level of service (LOS) was measured in order to indicate the velocity affected by parking or without parking. $\mathrm{C}=\mathrm{Co} \times \mathrm{F}_{\mathrm{CW}} \times \mathrm{FC}_{\mathrm{SP}} \times \mathrm{FC}_{\mathrm{SF}} \times \mathrm{FC}_{\mathrm{CS}}$

$C=1,650 \times 1.00 \times 1.00 \times 0.95 \times 0.90$

$\mathrm{C}=1410.8$

The capacity of the Cik Di Tiro street Yogyakarta is 1410.8, this capacity will be compared to the traffic volume to get the degree of highway saturation. The traffic volume are as follows:

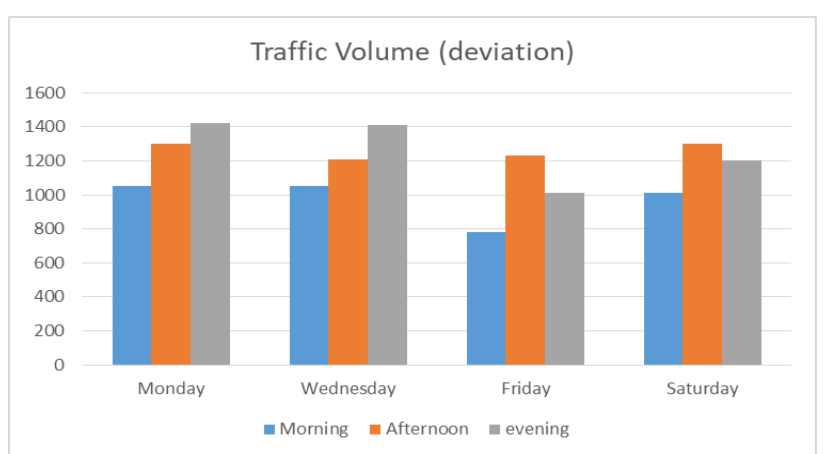

Figure 5. The Traffic Volume

from the graph it can be seen that traffic volumes that are close to capacity occur on Monday and Wednesday in the evening. Based on the graphic above, the average value of Level of Service are as follows:

Table 3. Level of Service and Degree of Saturation

\begin{tabular}{rrrr}
\hline Unit & Time & DS & LOS \\
\hline Week & Morning & 0,7363 & $\mathrm{C}$ \\
\cline { 2 - 4 } Days & Afternoon & 0,8996 & $\mathrm{E}$ \\
\cline { 2 - 4 } & Evening & 0,9525 & $\mathrm{E}$ \\
\hline Week & Morning & 0,5513 & $\mathrm{~A}$ \\
\cline { 2 - 4 } End & Afternoon & 0,8736 & $\mathrm{D}$ \\
\cline { 2 - 4 } & Evening & 0,7193 & $\mathrm{C}$ \\
\hline
\end{tabular}

Hence, based on the table, it can be explained that: a. During Weekdays, the traffic flow was nearly on unstable capacity and sometimes stops in the afternoon and evening. Meanwhile, in the morning, traffic flow was stable but the velocity and movement of the vehicle were controlled. 
b. In the Weekend, the traffic flow was free or the velocity was high in the morning, during the day the flow was nearly unstable, while in the afternoon the flow was stable but the velocity and movement of the vehicle were controlled.

\section{CONCLUSION}

On-street parking has a significant effect on decreasing vehicle velocity. The decrease in vehicle velocity has an impact on the level of service. When the traffic volume exceeds or approaches the road capacity, then congestion will occur. as shown by the analysis data, On weekdays, the data shows a decrease in vehicle velocity of 7.78 kilometers/hour due to on-street parking and a comparison of service levels due to the influence of on-street parking also gives a big effect, where without on-street parking service level is ' $\mathrm{C}$ ' which means the traffic flow is stable, velocity and movement are controlled whereas with on-street parking the level of service is ' $E$ ' which means the traffic flow is terrible / traffic congestion, low velocity, and any great traffic disruptions. On weekends, the data shows a decrease in vehicle velocity of 6.12 kilometers/hour due to parking on the road and a comparison of service levels due to the influence of on-street parking also gives a big effect, where without on-street parking the service level is ' $\mathrm{A}$ ' which means the traffic flow is free, high velocity, and no disruption while with on-street parking the level of service is ' $C$ ' and ' $D$ ', which means the traffic flow is nearly unstable, the velocity is controlled.

\section{ACKNOWLEDGMENT}

The researcher would like to say Thank you to all friends in Vocational and Technology Department who had assisted me in conducting this research. Also, the researcher would like to thank Ms. Retna Hidayah as the supervisor, who had supported the researcher.

\section{REFERENCES}

1. Widyaningrum, N. 2009. Kota dan Pedagang Kaki Lima. Journal Analisis Sosial, 14, 1.

2. Chiguma MLM, Bang K. 2007. Impact of individual side friction factors on free-flow speed: case study on urban road links in Dar-es-Salaam, Tanzania. 86th Annu. Meet. Transp. Res. Board (CD-ROM), Natl. Acad. Washingt. D.C.

3. Munawar, A. 2011. Speed and Capacity for Urban Roads, Indonesian Experience. Procedia - Social and Behavioral Sciences, 16, 382-387

4. Shoup, D. C. 2005. The High Cost of Free Parking American Planning Association, Chicago, Ill., 2005.

5. Davis, A., Pijanowski, B., Robinson, K., Engel, B., 2010. The environmental economic costs of sprawling parking lots in the United States. Land Use Policy 27 (2), 255-26

6. Khodaii, A., Aflaki, E., Moradkhani, A., 2010. Modeling the effect of parking fare on personal car use. Scientia Iranica - Trans. A Civ. Eng. 17 (3), 209-216.

7. Barata, E., Cruz, L., Ferreira, J.P., 2011. Parking at UC campus: problems and solutions. Cities 28 (5), 406-413.

8. Stockholmsstad. 2013. Mobility strategy: Parking plan Mars 2013 [in Swedish]. Available at: www.stockholm.se/trafikkontoret. (Dec. 2019).

9. Spililpoulou, C., Antoniou, C., 2012. Analysis of illegal parking behaviour in Greece. Procedia-Soc. Behav. Sci. 48. 2012, 1622-1631.

10. Biswas, S. Chandra, S. Ghosh, I. 2017. Effect of On-street parking in Urban Context: A Critical Review. Transp. in Dev. Econ. 3:10

11. Murray, A., 2001. Strategic analysis of public transport coverage. Socio-Econ. Plan. Sci. 35 (3), 175-188

12. Chick C. On-street Parking: A Guide to Practice. Landor Publishing: London, 1996.

13. Valleley M. Parking Perspectives: A Source Book For The Development Of Parking Policy. Landor Publishing: London, 1997.

14. Ye X, Chen J. Traffic delay caused by curb parking set in the influenced area of signalized intersection. ICCTP 2011: 2011; 566-578.
15. Badan Pusat Statistik. 2019. Yogyakarta Dalam Angka 2019. Yogyakarta.

16. Departemen pekerjaan umum. 1997. Manual Kapasitas Jalan Indonesia. Direktorat Jendral Bina Marga. Jakarta.

\section{AUTHORS PROFILE}

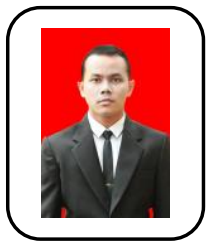

Benni Mustofa, S.Pd., was born in West Sumatera on March 5, 1995. He has 6 months as a teacher experience in vocational high School of percut sei tuan, medan indonesia. His educational background has graduate from bachelor's degree program in building engineering education, Currently $\mathrm{He}$ is studying postgraduate in Masteral of Vocational and Technology Education at State University of Yogyakarta. Research work: pengaruh model pembelajaran project based learning terhadap peningkatan hasil belajar mata pelajaran gambar teknik pada siswa kelas x program keahlian teknik gambar bangunan smk negeri 1 percut sei tuan. He is one of the member organization Ukmi Ar-Rahman State University of Medan. 2nd debate English competition in faculty of engineering state university of medan.

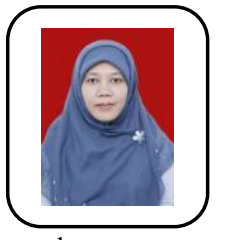

Retna Hidayah, ST., MT., Ph.D., She has 16 years experience as a lecturer in faculty of engineering of the state university of Yogyakarta. her educational background has graduate from bachelor's degree program in Architecture then graduate from master's degree in Arcihtecture, then graduate from Doctoral degree in Architecture of Kobe University. Research work:

1. Mitigasi dan rekonstruksi pasca gempa

2. The role of school, family, and society educations to achieve character building

3. Domestic Space Arrangement of the Private Rental Housing

4. Productive Settlement A way of Low-Income Urban Inhabitant Sustain the Community.pdf

5. Living at Urban Village an Access for Sustainable City

6. Inherited Housing System at Kampung Kauman.

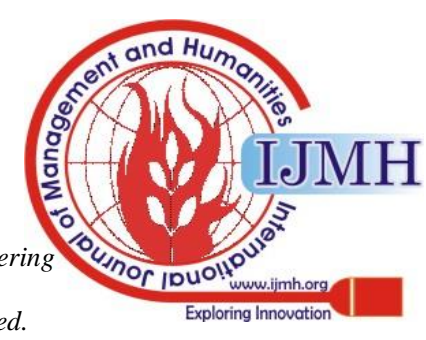

